\title{
APLIKASI PETA KENDALI STATISTIK DALAM MENGONTROL HASIL PRODUKSI SUATU PERUSAHAAN
}

\author{
Muhammad Arafat Abdullah \\ Jurusan Matematika FMIPA Universitas Sulawesi Barat \\ e-mail: $\underline{\text { arafatmandar@gmail.com }}$
}

\begin{abstract}
Abstrak
Paper ini membahas aplikasi peta kendali statistik untuk mengontrol hasil produksi markisa CV. Citra Sari Makassar yang bertujuan untuk mengetahui keberadaan proses tersebut dalam pengedalian statistik atau tidak dengan menggunakan peta kendali rata-rata $B K A=\stackrel{=}{X}+A_{2}(R)$ $, G T=\stackrel{\bar{X}}{X}, B K B=\stackrel{\bar{X}}{X}-A_{2}(R)$ dan peta kendali range dengan $B K A=\stackrel{-}{R} D_{4}, G T=\stackrel{-}{R}, B K B=\stackrel{-}{R} D_{3} f$ . Dari data jumlah produksi CV. Citra Sari Makassar, peta kendali rata-rata dengan $B K A=8045,98$ $G T=4418,96, B K B=791,94$ untuk peta kendali range dengan $B K A=13294,89, G T=6286, B K B=$ 0. Hasil menunjukkan Jumlah produksi markisa di CV. Citra Sari Makassar terkendali secara statistik.
\end{abstract}

Kunci Kunci: Peta Kendali statistik, Peta Kendali rata-rata, Peta Kendali Range

\section{PENDAHULUAN}

Dalam dunia industri, kualitas barang yang dihasilkan merupakan faktor yang sangat penting. Barang yang dihasilkan antara lain ditentukan kualitasnya berdasarkan pada pengukuran ataupun penilaian karakteristik-karakteristik tertentu. Hasil pengukuran yang dipakai untuk penentuan kualitas barang harganya berubah-ubah dari produk yang satu ke produk yang lainnya meskipun kondisi proses produksi dapat diusahakan sama (Sudjana, 2002: 419).

Perusahaan yang berproduksi tanpa memperhatikan kualitas produk atau jasa perusahaan, sama saja dengan menghilangkan harapan masa depan perusahaan tersebut, didalam jangka pendek, seakanakan perusahaan akan dapat menekan biaya produksi karena perusahaan tidak perlu mengeluarkan biaya pengendalian kualitas yang kadang-kadang bagi perusahaan-perusahaan tertentu menjadi sangat besar. Namun dalam jangka panjang, perusahaan yang tidak memperhatikan kualitas dari keluarannya akan mengalami macam kesulitan pemasaran oleh karena akan tersaingi oleh produk-produk yang sama yang diproduksi oleh perusahaan lain, atau jasa yang sama dari perusahaan yang lain pula dengan kualitas produk atau jasa yang lebih baik (Amyari, 1979: 237).

Kualitas diartikan sebagai kondisi yang selalu berubah (misalnya apa yang dianggap merupakan kualitas saat ini mungkin dianggap kurang berkualitas pada masa mendatang yang mencakup produk, jasa, manusia, dan lingkungan (Tjiono, F dan Dian, 2001). Pengendalian kualitas statistik merupakan teknik penyelesaian masalah yang digunakan untuk memonitor, mengendalikan, menganalisis, mengelola dan memperbaiki produk dan proses menggunakan metode-metode statistik pengendalian kualitas statistik (statistikal process control). Pengendalian kualitas statistik dan pengendalian proses statistik memang merupakan dua istilah yang saling dipertukarkan, Apabila dilakukan bersama-sama maka pemakai akan melihat gambaran kinerja proses masa kini dan masa mendatang (Cawley dan Harrold, 1999)

Untuk mengadakan perbaikan kualitas proses, menentukan kemampuan proses, membantu spesifikasi-spesifikasi yang efektif, menentukan kapan proses dijalankan dan kapan dibuat penyesuaiannya dan menemukan penyebab dari tidak diterimanya standar kualitas tersebut (produk) digunakan peta kendali statistik. Pengendalian kualitas statistik merupakan teknik penyelesian masalah yang digunakan untuk memonitor, mengendalikan, menganalisis, mengelolah dan memperbaiki produk dan proses dengan menggunakan metode-metode statistika.

Dengan adanya peta kendali memberikan manfaat yang sangat berarti bagi perusahaan antara lain Mengurangi pemborosan, Perbaikan pengendalian dalam proses, Peningkatan efisiensi, Perbaikan analisis dan monitoring proses. Dalam penelitian ini objek penelitian adalah adalah Perusahaan CV. Citra Sari di Jl. Manuruki II No. 69B Makassar yang bergerak dalam usaha produksi Sirup Markisa, 
akan diteliti sejauh mana trend dari produksi perusahaan yang dilakukan. Berdasarkan uraian diatas, peneliti ini mencoba mengaplikasikan peta kendali statistik dalam mengontrol hasil produksi perusahaan. Penelitian dibatasi pada pengaplikasikan peta kendali statistik yakni penggunaan peta kendali statistik untuk data variabel dengan menggunakan peta kendali rata-rata $(\bar{X})$ dan peta kendali jarak $(R)$ serta aplikasi peta kendali hanya digunakan untuk melihat apakah proses produksi perusahaan berada dalam pengendalian statistik atau tidak.

\section{TINJAUAN PUSTAKA}

Fungsi pengendalian kualitas statistik adalah Meningkatkan kualitas sehingga mengurangi ongkos manufaktur, scrap, rework, reschedulling, meningkatkan kepercayaan konsumen dan memperketat batas spesifikasi serta meningkatkan produktivitas dan hasil produksi. Peta kendali pertama kali diperkenalkan oleh Dr. Walter Andrew Shewhart dari Bell Telephone Laboratories, Amerika Serikat, pada tahun 1924 dengan maksud untuk menghilangkan variasi tidak normal melalui pemisahan variasi yang disebabkan oleh penyebab khusus (special-cause variation) dari variasi yang disebabkan oleh penyebab umum (common-causes variation). Peta kendali (control chart) merupakan metode statistik yang membedakan adanya variasi atau penyimpangan karena sebab umum dan karena sebab khusus pada batas pengendali. Bila penyimpangan atau kesalahan telah melebihi batas pengendali, menunjukkan bahwa penyebab khusus telah masuk dalam proses dan proses harus diperiksa untuk mengidentifikasi penyebab dari penyimpangan atau kesalahan yang berlebihan tersebut dan sebab umum biasanya berada di dalam batas pengendali (Gaspersz, 2001: 61).

Peta kendali terdiri atas tiga garis, dimana garis tengah disebut garis pusat (central line) merupakan target nilai pada beberapa kasus, kedua garis lainnya merupakan Batas Kendali Atas (BKA) dan Batas Kendali Bawah (BKB) dan karakteristik nilai dalam chart yang dilukiskan dalam state suatu proses. Berdasarkan uraian di atas, peta kendali adalah suatu grafik yang digunakan untuk mengevaluasi suatu proses produksi dari waktu ke waktu.

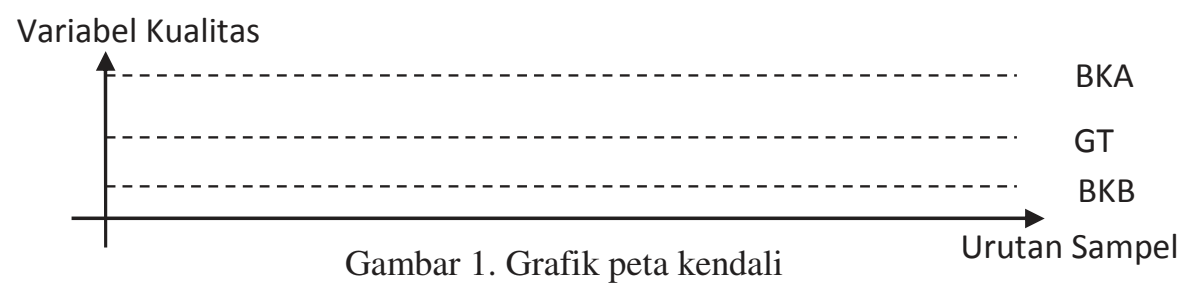

\section{Peta Kendali rata-rata $(\bar{X})$}

Peta pengendali rata-rata merupakan peta pengendali untuk melihat apakah proses masih berada dalam proses. Peta pengendali rata-rata menunjukkan apakah rata-rata produk yang dihasilkan sesuai dengan standar pengendalian yang digunakan perusahaan. Proses produksi dikatakan baik apabila produk yang dihasilkan berada disekitar garis pusat (center line). Namun, data yang berada di dalam peta pengendali statistik masih disebut sebagai berada dalam batas pengendalian statistik (in stattistical control) walaupun terdapat penyimpangan yang disebabkan oleh penyebab umum. Sementara data yang berada di luar batas pengendali rata-rata tersebut pasti disebut sebagai (out of statistikal control) yang disebabkan oleh penyebab khusus.

Peta pengendali rata-rata dapat digunakan untuk menganalisis proses ditinjau dari harga rata-rata variabel hasil proses, dengan tujuan mengumpulkan keterangan untuk:

1. Membuat atau mengubah spesifikasi, yaitu syarat-syarat yang harus dipenuhi oleh produk yang dihasilkan, atau untuk menentukan apakah proses yang sedang berlangsung dapat memenuhi spesifikasi.

2. Membuat atau mengubah cara produksi.

Peta pengendali rata-rata juga digunakan sebagai dasar pembuatan keputusan mengenai rata-rata variabel, selama produksi berjalan, apakah proses dibiarkan berlangsung ataukah dihentikan karena terdapat penyebab variasi tak wajar lalu diambil tindakan untuk melakukan perbaikan. Peta pengendali ini juga digunakan untuk menolak atau menerima produk yang dihasilkan atau yang dibeli.

Jika melakukan karakteristik kualitas dengan $x_{1}, x_{2}$, dan $x_{n}$ sampel berukuran n, maka rata-rata sampel adalah: 


$$
\bar{X}=\frac{x_{1}+x_{2}+\cdots+x_{n}}{n}=\frac{\sum_{i=1}^{n} x_{i}}{n}
$$

dimana $: \stackrel{\bar{X}}{=}=$ rata-rata pengukuran untuk setiap kali observasi

$n \quad$ = banyaknya sampel dalam tiap observasi atau sub kelompok

Untuk membuat peta kendali rata-rata dapat digunakan sifat-sifat distribusi sampling rata-rata

$x$. Sifat terpenting yang digunakan adalah bahwa rata-rata bedistribusi normal untuk ukuran sampel $n$ cukup besar dengan:

$$
\mu_{x}=\mu \text { dan } \sigma_{x}=\frac{\sigma}{\sqrt{n}}
$$

dimana : $\mu_{x}=$ rata-rata dari $x$

$$
\sigma_{x}=\text { simpangan baku dari } x
$$

Untuk $n$ dengan pengelompokkan untuk pengelompokkan sebesar empat sudah distribusi $\bar{X}$ dan sudah mendekati distribusi normal karena itulah, biasanya untuk pengotrolan kualitas sering digunakan sampel-sampel berukuran empat atau lima. Sekarang kita lihat bagaimana garis tengah,

batas kendali atas, batas kendali bawah untuk peta kendali rata-rata $\stackrel{-}{X}$ ditentukan. Jika $\mu$ diketahui, maka diambil garis tengah sama dengan $\mu$. Penentuan batas pengendali atas dan batas pengendali bawah tergantung pada besar peluang yang diinginkan untuk mendapatkan produk dalam kendali, jika populasinya berdistribusi normal dengan simpangan baku $\sigma$ yang diketahui dan menginginkan peluang produk dalam kendali sebesar 0,9973, maka:

$$
\mathrm{BKA}=\mu+\frac{3 \sigma}{\sqrt{n}} \text { dan } \mathrm{BKB}=\mu-\frac{3 \sigma}{\sqrt{n}}
$$

dimana: BKA $=$ Batas Kendali Atas

$$
\mathrm{BKB}=\text { Batas Kendali Bawah }
$$

Dalam hal ini telah digunakan diagram kendali 3 sigma, dimana diagram kendali tiga sigma ini dihitung berdasarkan distribusi normal terpusat. Jika menghendaki peluang produk dalam kendali sebesar 0,9545, yang identik dengan diagram kendali dua simpangan baku maka:

$$
\mathrm{BKA}=\mu+\frac{2 \sigma}{\sqrt{n}} \text { dan } \mathrm{BKB}=\mu-\frac{2 \sigma}{\sqrt{n}}
$$

Dalam praktek sesungguhnya, biasanya nilai $\mu$ tidak diketahui, oleh karena itu nilai-nilai tersebut harus ditaksir dari sampel dari sampel pendahuluan. Mis $\bar{X}_{1}, \bar{X}_{2}$ dan $\bar{X}_{n}$ adalah rata-rata setiap sampel, maka penaksiran terbaik untuk rata-rata proses adalah mean keseluruhan yaitu:

$$
\stackrel{=}{X}=\frac{\bar{X}_{1}+\bar{X}_{1}+\cdots+\bar{X}_{n}}{n}
$$

Jadi $\quad \mathrm{GT}=\stackrel{=}{X}$

dimana: GT = Garis Tengah

Sehingga pada peta kendali rata-rata dapat ditentukan nilai garis tengah, batas kendali atas dan batas kendali bawah sebagai berikut (misalkan untuk diagram kendali 3 sigma): 


$$
\mathrm{BKA}=\stackrel{\overline{=}}{X}+3 \sigma_{x}=\stackrel{\bar{X}}{X}+\frac{3 \sigma}{\sqrt{n}}, \mathrm{GT}=\stackrel{\bar{X}}{X}, \mathrm{BKA}=\stackrel{\bar{X}}{X}-3 \sigma_{x}=\stackrel{\bar{X}}{X}-\frac{3 \sigma}{\sqrt{n}}
$$

karena $\sigma=\frac{R}{d_{2}}$ maka batas pengendali pada peta kendali rata-rata adalah:

$\mathrm{BKA}=\stackrel{\bar{X}}{X}+3 \sigma_{x}=\stackrel{\bar{X}}{X}+\frac{3 \sigma}{\sqrt{n}}=\stackrel{\overline{=}}{X}+\frac{3}{d_{2} \sqrt{n}} \stackrel{-}{R}, \mathrm{GT}=\stackrel{\bar{X}}{X}, \mathrm{BKA}=\stackrel{=}{X}-3 \sigma_{x}=\stackrel{\bar{X}}{X}-\frac{3 \sigma}{\sqrt{n}}=\stackrel{\bar{X}}{X}-\frac{3}{d_{2} \sqrt{n}} \stackrel{-}{R}$, jika $\frac{3}{d_{2}}=A_{2}$, maka nilai BKA, GT dan BKB diatas dapat dihitung dengan menggunakan persamaan sebagai berikut:

$$
\begin{aligned}
& \mathrm{BKA}=\stackrel{\overline{=}}{\mathrm{X}}+3 \sigma_{x}=\stackrel{\overline{=}}{X}+\frac{3 \sigma}{\sqrt{n}}=\stackrel{\overline{=}}{X}+\frac{3}{d_{2} \sqrt{n}}(R)=\stackrel{\overline{ }}{X}+A_{2}(R), \mathrm{GT}=\stackrel{=}{=} \\
& \mathrm{BKA}=\stackrel{\overline{=}}{X}-3 \sigma_{x}=\stackrel{\bar{X}}{X}-\frac{3 \sigma}{\sqrt{n}}=\stackrel{\bar{X}}{X}-\frac{3}{d_{2} \sqrt{n}}(R)=\stackrel{\bar{X}}{=}-A_{2}(R)
\end{aligned}
$$

\section{Peta Kendali Jarak (Range)}

Peta kendali jarak (range) digunakan untuk mengetahui tingkat keakurasian atau ketepatan proses yang diukur dengan range dari sampel yang diambil dalam observasi. Seperti halnya pada pengendali rata-rata, peta pengendali jarak tersebut digunakan untuk mengetahui dan menghilangkan penyebab khusus yang membuat terjadinya penyimpangan. Data yang berada data yang berada di dalam batas pengendalian statistik untuk range disebut in statistikal control yang terdapat penyimpangan karena penyebab umum. Sementara data yang berada diluar batas pengendali statistik untuk range disebut sebagai out statistikal control yang disebabkan oleh sebab khusus.

Untuk membuat batas pengendalian, perlu ditaksir standar deviasi $(\sigma)$ atau rentang m sampel. Jika $x_{1}, x_{2}$ dan $x_{n}$ adalah sampel berukuran $n$, maka rentang sampel adalah selisih nilai observasi terbesar dengan nilai observasi terkecil atau

$$
R=X_{\max }-X_{\min }
$$

misalkan, $R_{1}, R_{2}$, dan $R_{m}$ adalah rentang $m$ sampel, maka rentang rata-ratanya adalah:

$$
\stackrel{-}{R}=\frac{R_{1}+R_{2}+\cdots+R_{m}}{m}
$$

dimana: $\stackrel{\overline{=}}{R} \quad$ = rata-rata rentang dari setiap observasi

$m \quad$ = banyaknya sampel dalam tiap observasi

Seperti halnya untuk diagram kendali rata-rata, maka untuk diagram kendali $R$ juga diperlukan garis tengah, batas kendali atas dan batas kendali bawah. Jika populasinya berdistribusi normal dengan parameter rata-rata $\mu$ dan simpangan baku $\sigma$ pada $R$ diketahui. Maka rata-rata berdistribusi normal untuk ukuran sampel $n$ cukup besar dengan:

$\mu_{R}=\mu=\bar{R} \operatorname{dan} \sigma_{R}=\frac{\sigma}{\sqrt{n}}$

dimana: $\mu_{R}=$ rata-rata dari $R$

$$
\sigma_{R}=\text { Simpangan baku dari } R
$$

Dengan menggunakan 3 sigma dapat ditentukan BKA dan BKB sebagai berikut: 


$$
\mathrm{BKA}=\mu+3\left(\sigma_{R}\right)=\mu+3\left(\frac{\sigma}{\sqrt{n}}\right), \mathrm{BKB}=\mu-3\left(\sigma_{R}\right)=\mu-3\left(\frac{\sigma}{\sqrt{n}}\right)
$$

Jika simpangan baku $\sigma$ ditaksir oleh $=\frac{-}{d_{2}}$, dimana $d_{2}$ untuk berbagai ukuran sampel dapat dilihat dalam tabel lampiran faktor guna membentuk grafik pengendali varabel. Jika digunakan $\bar{u}$ sebagai penaksir untuk $\mu$ dan $\frac{\bar{R}}{d_{2}}$ sebagai penaksir parameter grafik $R$ untuk menentukan $R$, BKA dan BKB. Jika kita menggunakan peta kendali jarak (range) dapat ditentukan dengan mudah, yaitu GT nya adalah $R$. Untuk menetukan BKA dan BKB atau batas pengendalian perlu ditaksir nilai $\sigma_{R}$. Jika dianggap bahwa karakteristik kualitas berdistribusi normal, maka estimasi $\sigma_{R}$ dapat diperoleh dari distribusi rentang relatif, yaitu $W=\frac{R}{\sigma}$. Jika standar deviasi $W=d_{2}$, maka $R=w_{\sigma}$. Standar deviasi $R$ adalah: $\sigma_{R}=d_{3}$. Oleh karena $\sigma$ tidak diketahui maka kita dapat menaksir $\sigma_{R}$ dengan menggunakan persamaan $\sigma_{R}=d_{3}\left(\frac{\bar{R}}{d_{2}}\right)$.

Dengan demikian, jika kita menggunakan batas pengendalian 3-sigma, maka parameter peta kendali range dapat ditentukan dengan persamaan sebagai berikut:

$$
B K A=\stackrel{-}{R}+3 \sigma_{R}=\stackrel{-}{R}+3 d_{3}\left(\frac{-}{d_{2}}\right), G T=\stackrel{-}{R}, B K B=\stackrel{-}{R}-3 \sigma_{R}=\stackrel{-}{R}+3 d_{3}\left(\frac{-}{d_{2}}\right)
$$

jika dituliskan $D_{3}=1-3\left(\frac{d_{3}}{d_{2}}\right)$ dan $D_{4}=1+3\left(\frac{d_{3}}{d_{2}}\right)$, maka parameter peta kendali range dapat ditulis dengan persamaan sebagai berikut:

$$
B K A=\bar{R} D_{4}, G T=\bar{R}, B K B=\bar{R} D_{3}
$$

konstanta $D_{3}$ dan $D_{4}$ untuk berbagai ukuran sampel atau nilai $n$ dapat dilihat dalam tabel lampiran faktor guna membentuk grafik pengendali varabel.

\section{Sumber Data}

\section{METODOLOGI PENELITIAN}

Data yang digunakan adalah data sekunder yakni data jumlah hasil produksi pada CV. Citra Sari tiap bulan pada tahun 2006-2008.

\section{Analisis Data}

Data yang diperoleh dari hasil penelitian selanjutnya dianalisis secara kuantitatif. Dari data diatas kita dapat mengetahui sejauh mana hasil produksi dalam kondisi terkendali dengan menggunakan metode pengendalian kualitas statistik yakni dengan peta kendali. Karena data diatas dalam bentuk variabel maka digunakan peta kendali rata-rata dan peta kendali range untuk mengendalikan hasil produksi diatas dan untuk mengetahui variasi penyebab khusus pada proses yang ditandai dengan adanya data yang keluar dari kontrol. Langkah-langkah dalam pembuatan peta kendali rata-rata dan peta kendali range adalah sebagai berikut:

1. Tentukan ukuran contoh $(n=4,5,6, \ldots)$. Untuk keperluan praktek biasanya ditentukan lima unit pengukuran dari setiap contoh $(n=5)$.

2. Kumpulkan set $20-25$ set contoh (paling sedikit dari $60-100$ ) titik data individual.

3. Hitunglah nilai rata-rata dari tiap set contoh $(\bar{X})$, dan $\mathrm{R}$ dari setiap set contoh. 


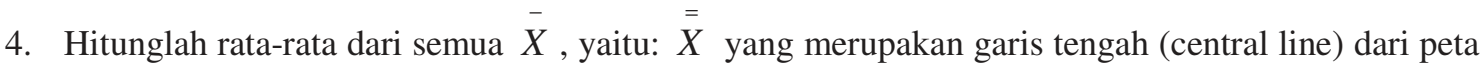
kendali rata-rata, serta nilai rata-rata dari semua $\mathrm{R}$, yaitu: $\bar{R}$ yang merupakan garis tengah (central line) dari peta kendali R.

5. Hitung batas-batas kendali 3 sigma dari peta kendali rata-rata dan peta kendali R.

- Peta Kendali Rata-rata (batas-batas kendali 3-sigma)

$$
\mathrm{BKA}=\stackrel{\bar{X}}{X}+A_{2}(\stackrel{-}{R}), \mathrm{GT}=\stackrel{\bar{X}}{X}, \mathrm{BKA}=\stackrel{\bar{X}}{X}-A_{2}(\stackrel{-}{R})
$$

- Peta Kendali Range (batas-batas kendali 3-sigma)

$$
B K A=\stackrel{-}{R} D_{4}, G T=\stackrel{-}{R}, B K B=\stackrel{-}{R} D_{3}
$$

6. Buatlah peta kendali rata-rata dan peta kendali range menggunakan batas-batas kontrol tiga sigma diatas. Setelah itu plot dan tebarkan data $\bar{X}$ dan $\mathrm{R}$ dari setiap contoh yang diambil pada peta kendali rata-rata dan peta kendali $\mathrm{R}$ serta lakukan pengamatan apakah data itu berada dalam pengendalian statistikal.

7. Apabila proses berada dalam pengendalian (proses stabil), maka hitung indeks kapabilitas proses, $\mathrm{Cp}$, dan indeks kinerja kane, Cpk, sebagai berikut:

$\mathrm{Cp}=\frac{(U S L-L S L)}{6 \sigma}$ dimana : $\sigma=\frac{\bar{R}}{d_{2}}$, Batas spesifikasi (USL dan LSL): $\underset{X}{X} \pm 0,05$

Jika $\mathrm{Cp} \geq 1$ maka proses dalam keadaan kapabel dan jika $\mathrm{Cp} \leq 1$ maka proses dalam keadaan tidak kapabel

$\mathrm{Cpk}=\min \left(\mathrm{C}_{\mathrm{pA}} ; \mathrm{C}_{\mathrm{pB}}\right)$ dimana: $\mathrm{C}_{\mathrm{pA}}=\frac{U S L-\bar{x}}{3 \sigma}$ dan $\mathrm{C}_{\mathrm{pA}}=\frac{\bar{x}-L S L}{3 \sigma}$

jika $\mathrm{C}_{\mathrm{pk}} \geq 1$ maka proses dalam keadaan baik dan jika $\mathrm{C}_{\mathrm{pk}}<1$ maka proses dalam keadaan tidak baik.

Indeks kapabilitas proses baru digunakan untuk dihitung proses berada dalam pengendalian.Gunakan peta kendali rata-rata dan peta kendali range untuk memantau proses yang sedang berlangsung dari waktu ke waktu, untuk seterusnya segera diambil tindakan perbaikan apabila ada tampak perubahanperubahan yang tidak diinginkan pada proses.

Data Hasil Produksi CV. Citra Sari Makassar

\section{HASIL DAN PEMBAHASAN}

Data yang dipakai pada penelitian ini adalah data jumlah produksi markisa CV. Citra Sari pada tahun 2006 sampai tahun 2008.

Tabel 1 Jumlah hasil produksi markisa pada CV. Citra Sari Makassar tahun 2006-2008.

\begin{tabular}{|l|c|l|c|c|c|}
\hline \multicolumn{2}{|c|}{ Tahun 2006 } & \multicolumn{2}{c|}{ Tahun 2007} & \multicolumn{2}{c|}{ Tahun 2008 } \\
\hline \multicolumn{1}{|c|}{ Bulan } & Jumlah Produksi & \multicolumn{1}{c|}{ Bulan } & Jumlah Produksi & Bulan & Jumlah Produksi \\
\hline Januari & 3982 & Januari & 4340 & Januari & 2170 \\
\hline Februari & 5250 & Februari & 3982 & Februari & 4130 \\
\hline Maret & 1680 & Maret & 1610 & & \\
\hline April & 2100 & April & 2240 & & \\
\hline Mei & 2240 & Mei & 1470 & & \\
\hline Juni & 1820 & Juni & 1562 & & \\
\hline Juli & 3710 & Juli & 3640 & & \\
\hline Agustus & 3990 & Agustus & 9100 & & \\
\hline September & 6020 & September & 4830 & & \\
\hline Oktober & 7560 & Oktober & 12530 & & \\
\hline November & 10850 & November & 7280 & & \\
\hline Desember & 2730 & Desember & 3640 & & \\
\hline
\end{tabular}


Pembuatan Peta Kendali Rata-rata dan Peta Kendali Range

Pembuatan peta kendali rata-rata dan peta kendali range dapat dilakukan dengan sebagai berikut:

1. Ditentukan ukuran contoh $(\mathrm{n}=3,4,5,6, \ldots)$ karena sedikitnya jumlah data hasil produksi pada CV. Citra Sari maka digunakan ukuran contoh $n=5$.

2. kumpulkan set contoh, karena jumlah data yang diperoleh dari CV. Citra Sari pada tahun 20062008 yaitu 25 data maka set contoh diperoleh sebanyak 5 set contoh.

Untuk lebih jelasnya dapat dilihat pada tabel 5 berikut.

Tabel 2. Penentuan ukuran contoh dan set contoh pada data jumlah produksi markisa pada tahun 2006 sampai tahun 2008.

\begin{tabular}{|c|c|c|c|c|c|c|c|c|}
\hline \multirow[b]{2}{*}{$\begin{array}{c}\text { Contoh } \\
\text { (Sampel) }\end{array}$} & \multicolumn{5}{|c|}{ Pengukuran Pada Unit Contoh $(n=5)$} & \multicolumn{3}{|c|}{ Perhitungan yang perlu } \\
\hline & $x_{1}$ & $x_{2}$ & $x_{3}$ & $x_{4}$ & $x_{5}$ & Jumlah & $\begin{array}{c}\text { Rata-rata } \\
(\bar{X})\end{array}$ & $\begin{array}{l}\text { Range } \\
(R)\end{array}$ \\
\hline 1. & 5250 & 1680 & 2100 & 2240 & 1820 & 13090 & 2618 & 3570 \\
\hline 2. & 3710 & 3990 & 6020 & 7560 & 10850 & 32130 & 6426 & 7140 \\
\hline 3. & 2730 & 4340 & 3982 & 1610 & 2240 & 14902 & 2980,4 & 2730 \\
\hline 4. & 1470 & 1562 & 3640 & 9100 & 4830 & 20602 & 4120,4 & 7630 \\
\hline 5. & 12530 & 7280 & 3640 & 2170 & 4130 & 29750 & 5950 & 10360 \\
\hline & & & & & & $\begin{aligned} \text { Jumlah } & = \\
\text { Rata-rata } & =\end{aligned}$ & $\begin{array}{l}220094,8 \\
4418,96 \\
= \\
X=4418,96\end{array}$ & $\begin{array}{c}31430 \\
6286 \\
-\quad \\
R=6286\end{array}$ \\
\hline
\end{tabular}

3. Menghitung nilai rata-rata dari semua $\bar{X}$ yaitu $\stackrel{\bar{X}}{X}=4418,96$ yang merupakan garis tengah (GT) dari peta kendali rata-rata, serta nilai rata-rata dari semua $\mathrm{R}$, yaitu: $\bar{R}=6286$ yang merupakan garis tengah (GT) dari peta kendali R.

4. Menghitung batas-batas kotrol 3 sigma karena kita menginginkanpeluang produk dalam kotrol sebesar 0,9973, maka peta kendali rata-rata dan peta kendali R sebagai berikut:

- Peta kendali rata-rata (batas-batas kotrol 3 sigma)

$$
\begin{aligned}
& \text { BKA }=\stackrel{\bar{X}}{=}+A_{2} \stackrel{-}{R}=4418,96+(0,577)(6286)=8045,98 \\
& \text { GT } \quad=\stackrel{\bar{X}}{=}=4418,96 \\
& \mathrm{BKB}=\stackrel{\bar{X}}{\mathrm{X}}-A_{2} \stackrel{-}{R}=4418,96-(0,577)(6286)=791,94
\end{aligned}
$$

penentuan nilai $A_{2}$ dapat dilihat pada lampiran faktor guna membentuk grafik pengendali variabel.

- Peta kendali range (batas-batas kontrol 3 sigma)

BKA $=D_{4} \cdot \bar{R}=(2,115) \cdot 6286=13294,89$

$\mathrm{GT} \quad=\bar{R}=6286$

$\mathrm{BKB}=D_{3} \stackrel{-}{R}=(0) \cdot 6286=0$

Penentuan nilai $D_{4}$ dan $D_{3}$ dapat dilihat pada lampiran I faktor guna membentuk grafik pengendali variabel.

5. Buatlah peta kendali rata-rata dan peta kendali $\mathrm{R}$ dengan menggunakan batas kendali diatas. Dengan menggunakan program minitab 14 kita membuat peta kendali rata-rata dan peta kendali rang 


\section{X-bar Chart for Jumlah Produksi Markisa CV. Citra Sari}

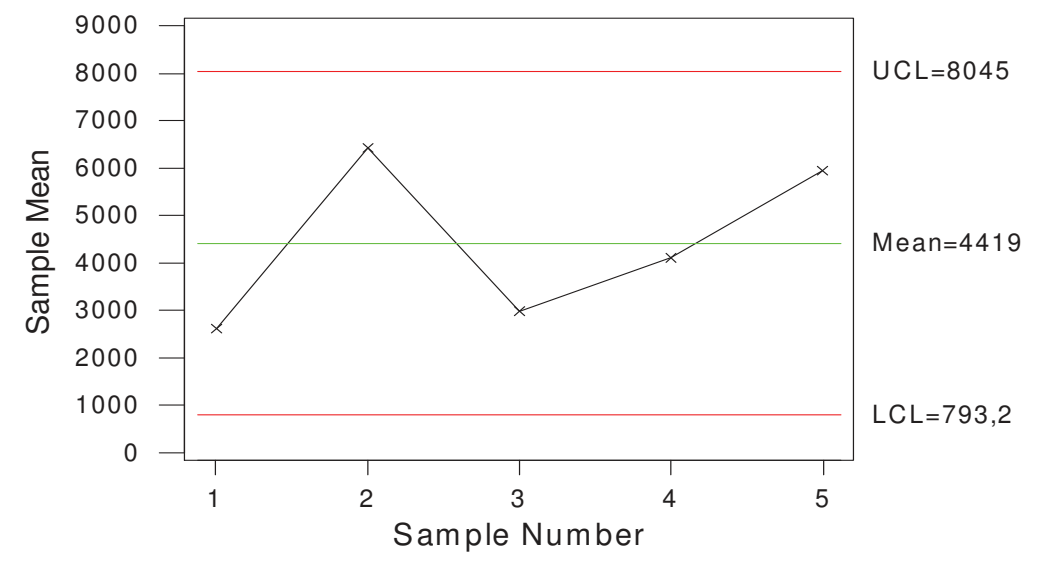

Gambar 2. Peta Kendali Rata-rata Produksi Markisa CV. Citra Sari, TAHUN 2006 sampai tahun 2008.

\section{R Chart for Jumlah Produksi Markisa C V. Citra Sari}

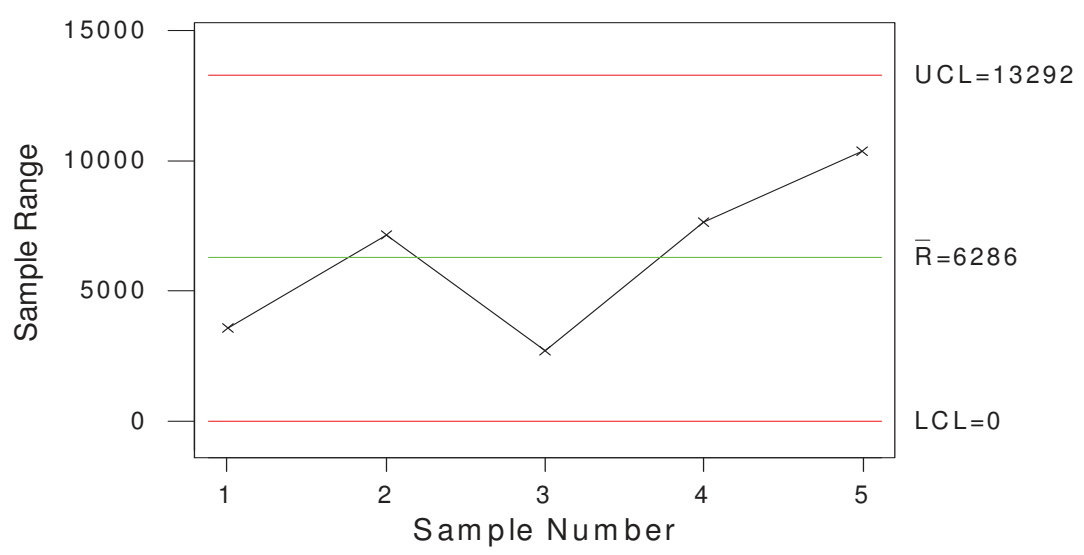

Gambar 3 Peta Kendali Range Produksi Markisa CV. Citra Sari, tahun 2006 sampai tahun 2008.

Dapat dilihat dari peta kendali rata-rata dan peta kendali range dari data hasil produksi markisa pada tahun 2006-2008 dalam kondisi terkendali hal ini dapat dilihat dari data yang berada dalam peta kendali tidak ada yang keluar dari batas kendali.

6. Karena proses sudah stabil maka hitung indeks proses (Cp), dan indeks kanerja Kane (Cpk), sebagai berikut:

$$
\begin{aligned}
& C p=\frac{(U S L-L S L)}{6 \sigma} ; \text { dimana } \sigma=\frac{\bar{R}}{d_{2}}=\frac{6286}{2,326}=2702,49 \\
& \mathrm{USL}=\stackrel{=}{X}+0,06=4418+0,06=4419,02 \\
& \mathrm{LSL}=\stackrel{\bar{X}}{X}-0,04=4418-0,04=4418,92
\end{aligned}
$$




$$
\begin{aligned}
& \text { Jadi } C p=\frac{(U S L-L S L)}{6 \sigma}=\frac{4419,02-4418,92}{6 \cdot 270249}=\frac{0,1}{16214,94}=6,18 \\
& C p k=\min (C P L, C P U) \quad \text {, dimana: } \\
& C P L=\frac{\bar{X}-L S L}{3 \cdot 6 \sigma}=\frac{4418,96-4418,92}{\frac{-}{R}}=\frac{4418,96-4418,92}{3 \cdot 2702,49}=\frac{0,04}{88107,47}=4,93 \\
& C P U=\frac{U S L-X}{3 \cdot 6 \sigma}=\frac{4419,02-4418,96}{d_{2}}=\frac{4419,02-4418,96}{3 \cdot 2702,49}=\frac{0,06}{88107,47}=7,40
\end{aligned}
$$

Jadi

$$
C p k=\min (4,93 ; 7,40)=4,93
$$

Karena $C p \geq 1$ maka proses dalam keadaan kapabel, dan $C p k \geq 1$ maka proses dalam keadaan baik.

Setelah perhitungan Indeks Kapabilitas Proses dan indeks kinerja Kane, diperoleh bahwa proses dalam keadaan kapabel dan proses dalam keadaan baik maka dapat diketahui bahwa proses produksi di CV. Citra Sari Makassar berada dalam batas pengendalian statistik. Hal ini disebabkan oleh manajemen produksi yang cukup baik, yaitu dari aspek tenaga kerja, mesin dan pengadaan bahan baku yang selalu tersedia selama proses produksi pada CV. Citra sari Makassar, selain itu manajemen pemasaran pada CV. Citra Sari Makassar juga cukup baik, karena adanya rantai pemasaran yang jelas mulai dari produsen ke distributor lalu sampai ke konsumen atau proses pemasaran langsung dari produsen ke konsumen, jangkauan pasarnya juga cukup luas hingga sampai ke daerah lain contohnya pulau jawa.

\section{KESIMPULAN}

Perusahaan CV. Citra Sari memproduksi sirup markisa, pada analisis awal data produksi perusahaan berada dalam batas pengendalian statistik atau terkendali, setelah penghitungan Indeks Kapabilitas Proses $(\mathrm{Cp})$ dan Indeks Kanerja Kane (Cpk) maka proses produksi kapabel sehingga peta kendali ratarata dan peta kendali range untuk data jumlah produksi pada CV. Citra Sari Makassar dapat dijadikan sebagai alat dalam mengontrol jumlah produksi yang akan datang.

\section{DAFTAR PUSTAKA}

Amyari, Agus., 1979. Manajemen Pengendalian Produksi. Penerbit BPFE Yogyakarta.

Assauri, Sofjan., 1993. Manajemen Produksi Dan Operasi. Penerbit Fakultas Ekonomi Universitas Indonesia Jakarta.

Ariani, D. W., 2003. Pengendalian Kualitas Statistik. Penerbit Andi Yoyakarta.

Gaspers, V., 2001. Metode Analisis Untuk Peningkatan Kualitas. Penerbit PT. Gramedia Pustaka Utama Jakarta.

Gitosudarmo, Indriyo., 1998. Manajemen Operasi. Penerbit BPFE Yogyakarta.

Montgomery, D. C., 1991. Introduction to Statistikal Quality Control. Newyork: Prentice Hall, Englewood Cliffs

Reksohadiprodjo, S \& Gitosudarmo, I., 1986. Manajemen Produksi. Penerbit BPFE Yogyakarta. Sudjana., 2002. Metode Statistika. Penerbit PT. Tarsito Bandung.

Yamit, Zulian., 2001. Manajemen Kualitas. Penerbit Ekonosia Kampus Fakultas Ekonomi UII Yogyakarta. 